\title{
Migrenli Bireylerin Klinik Özellikleri ve Fiziksel Aktivite İlişsisi
}

\section{Clinical Features of Individuals with Migraine and Physical Activity Relationship}

\author{
Hafize ALTAY ${ }^{1 \text { A,B,C,D,E,F,G }}$, Şeyda TOPRAK ÇELENAY $^{2}$ A,B,D,F,G Ç$_{\mathbb{0}}$ \\ ${ }^{1}$ Ankara Yıldırım Beyazıt Üniversitesi, Sağlık Bilimleri Enstitüsü, Fizyoterapi ve Rehabilitasyon Anabilim Dalı, Fizyoterapi \\ ve Rehabilitasyon Yüksek Lisans Programı, Ankara, Türkiye \\ ${ }^{2}$ Ankara Yıldırım Beyazıt Üniversitesi, Sağlık Bilimleri Fakültesi, Fizyoterapi ve Rehabilitasyon Bölümü, Ankara, Türkiye
}

ÖZ

\begin{abstract}
Amaç: Migrenli bireylerin klinik özelliklerini belirlemek ve bu özellikler ile fiziksel aktivite arasındaki ilişkiyi saptamaktı. Yöntem: Çalışmaya 310 migrenli birey dahil edildi. Migrenin ağrı karakteristiği ve klinik semptomları sorgulandı. Fiziksel aktivite seviyesi, migrene bağlı özür durumu ve yaşam kalitesi sırasıyla Uluslararası Fiziksel Aktivite Anketi kısa form ile, Migren Özür Değerlendirme Skalası ile ve Baş Ağrısı Etki Ölçeği ile değerlendirildi.

Bulgular: Bireylerin son bir aydaki ortalama ağrı şiddeti, atak sayısı ve süresi sırasıyla 8 (4-10), 4 (1-30) ve 120 (50-4320) dk olarak bulundu. Bireylerin \%89.7 sinin $(\mathrm{n}=278)$ aura yaşadığı saptandı. Bireylerin atak sırasında en çok fotofobi (\%91.3; n=283) ve fonofobi (\%95.2; n=295) şikayeti olduğu belirlendi. Migren Özür Değerlendirme Skalası ve Baş Ağrısı Etki Ölçeği skorlar1 sırasıyla $24.0(1.0-180.0)$ ve 66.0 (38.0-78.0) idi. Bireylerde fiziksel aktivite düzeyi ile ağr1 şiddeti (rho=-0.022; $\mathrm{p}=0.730)$, atak sayıs $(\mathrm{rho}=0.070 ; \mathrm{p}=0.221)$ ve süresi $(\mathrm{rho}=-0.057 ; \mathrm{p}=0.318)$, migrene bağlı özür durumu $(\mathrm{rho}=0.005 ; \mathrm{p}=0.932)$ ve yaşam kalitesi (rho=-0.021; $\mathrm{p}=0.714$ ) arasında bir ilişki yoktu.

Sonuç: Bireylerin migren atakları sırasında şiddetli ağrı ve aura yaşadığı, migrenle ilişkili en çok ciddi özür durumu olduğu ve yaşam kalitesinde en çok şiddetli etkilenimi olduğu bulundu. Bireylerin büyük çoğunluğunun fiziksel olarak aktif olmadığ tespit edildi. Fakat fiziksel aktivite düzeyi ile ağrı karakteristiği, özür durumu ve yaşam kalitesi arasında bir ilişki görülmedi.
\end{abstract}

Anahtar Kelimeler: Fiziksel aktivite, Migren, Baş ağrıs1.

\section{ABSTRACT}

Objective: To determine the clinical characteristics of individuals with migraine and to determine the relationship between these characteristics and physical activity.

Methods: In the study, 310 individuals with migraine were included. Pain characteristic and clinical symptoms of migraine were questioned. Physical activity levels, migraine-related disability status and quality of life were evaluated with International Physical Activity Questionnaire, Migraine Disability Assessment Scale and Headache Impact Test, respectively.

Results: The average pain intensity, number and duration of attacks of individuals during the last month was found as 8 (4-10), 4 (1-30) and 120 (50-4320) minutes, respectively. It was detected that $89.7 \%(\mathrm{n}=278)$ of individuals experienced aura. It was determined mostly photophobia $(91.3 \% ; \mathrm{n}=283)$ and phonophobia $(95.2 \% ; \mathrm{n}=295)$ complaints individuals during the attack. The Migraine Disability Assessment Scale and Headache Impact Test scores were 24.0 (1.0-180.0) and 66.0 (38.0-78.0), respectively. There were no relationship between physical activity level and pain intensity ( $r h o=-0.022 ; p=0.730)$, number of attacks $(\mathrm{rho}=0.070 ; \mathrm{p}=0.221$ ) and duration ( $\mathrm{rho}=-0.057 ; \mathrm{p}=0.318)$, migraine-related disability $(\mathrm{rho}=0.005 ; \mathrm{p}=0.932)$ and quality of life (rho=-0.021; $\mathrm{p}=0.714)$.

Conclusion: It was found that the individuals experienced severe pain intensity and aura, the most severe migraine-related disability, and the most severe impact on quality of life during migraine attacks. It was found that the vast majority of individuals were not physically active. However, it was not observe a relationship between physical activity level and pain characteristic, disability and quality of life.

Key words: Physical activity, Migraine, Headache.

Sorumlu Yazar: Şeyda TOPRAK ÇELENAY

Ankara Yıldırım Beyazıt Üniversitesi, Sağlık Bilimleri Fakültesi, Fizyoterapi ve Rehabilitasyon Bölümü, Ankara, Türkiye sydtoprak@hotmail.com

Geliş Tarihi: 26.04.2021 - Kabul Tarihi: 27.07.2021

Yazar Katkıları: A) Fikir/Kavram, B) Tasarım, C) Veri Toplama ve/veya İşleme, D) Analiz ve/veya Yorum, E) Literatür

Taraması, F) Makale Yazımı, G) Eleştirel İnceleme 


\section{GİRiş}

Migren; genetik duyarlılığı olan kişilerde, tetikleyici faktörlerle ortaya çıkan orta ve şiddetli baş ağrısı atakları ile karakterize genellikle tek taraflı ve/veya zonklayıcı, rutin fiziksel aktivite ile tetiklenebilen, bulantı, kusma, fotofobi ve fonofobinin eşlik ettiği multifaktöriyel nörovasküler bir sendromdur. Bazı hastalarda, ataklara fokal nörolojik semptomları olan aura eşlik edebilir (1). Genel popülasyonun yaklaşık \%10'undan fazlasını etkileyen genç erişkinlerde ortaya çıkan migren kişilerin sosyal yaşamını kısıtlaması, mesleki yaşamını olumsuz etkilemesi, iş gücü kaybı oluşturması, fiziksel ve emosyonel fonksiyonlarını sınırlandırması nedeniyle yaşam kalitesini azaltır ve özre neden olur (2). Migren; 2015 yılında yapılan Küresel Hastalık Yükü Çalışmasında dünya çapında 50 yaşın altındaki hem erkeklerde hem de kadınlarda üçüncü en yüksek engellik nedeni olarak belirlenmiştir (3).

Migrenin klinik görünümünde hem hastalar arasında hem de bireysel bir hastada ataklar arasında önemli değişkenlikler vardır (4). Migren ataklarının genel özellikleri, hastalar arasındaki değişkenliklerin ayrıntılı bir biçimde açıklanması önemlidir (5). Bilgimiz dahilinde Türk toplumunda migren klinik özelliklerinin sorgulandığı sınırlı sayıda çalışma vardır ve genellikle mevcut çalışmalar migren prevalansını belirlemeye ve/veya migren ile ilişkili özür durumunu sorgulamaya yöneliktir (6-8).

Fiziksel aktivite, iskelet kasının kasılmasıyla üretilen ve enerji tüketimini önemli ölçüde artıran fiziksel hareket olarak tanımlanır. Bu nedenle bu terim, spor ve egzersizden günlük yaşamda yer alan hobilere veya aktivitelere kadar insanların tüm hareketlerini kapsar (9). Fiziksel aktivitenin; bireyin fiziksel uygunluk düzeyi, dayanıklılık, kuvvet, esnekliğinde artış sağlamada ayrıca bireyin duygusal durumu ve sosyal ilişkilerinde iyileşmeyi arttırması gibi birçok alanda yararlı etkileri olduğu belirtilmektedir (10). Bunların yanı sıra fiziksel egzersizin kronik ağrının önlenmesinde ve kronik ağrıya sahip popülasyonlarda devam eden ağr semptomlarını azaltmak için uygun bir yöntem olabileceğine yönelik artan kanıtlar vardır (11). Ellingson ve ark. (2012) yaptıkları çalışmada, daha yüksek fiziksel aktiviteye sahip bireylerin ağr yoğunluğunun ve rahatsızlık derecelerinin daha az olduğunu bulmuşlardır (12). Benzer bir şekilde Adrzejewski ve ark. (2010) tarafindan basınç ağrı eşiklerinin değerlendirildiği bir çalışmada da sadece orta derecede fiziksel aktiviteye katıldığını bildirenlere kıyasla şiddetli fiziksel aktivite yaptığını bildirenlerin daha yüksek ağrı eşiğine sahip olduğunu ortaya koymuşlardır (13). Düzenli yapılan fiziksel aktivite ve egzersizin, migren ataklarında iyileşmeye katkı sağlayabileceğini ifade eden çalışmalar da vardır (14-16).

Ayrıca çeşitli toplum temelli çalışmalar, düşük fiziksel aktivite seviyelerinin daha yüksek migren ve diğer baş ağrıları prevalansı ile ilişkili olduğu sonucuna varmışlardır $(17,18)$. Diğer bir yandan da migrende belirlenen tetikleyici faktörler arasında fiziksel aktivite de yer almaktadır (19). Migrenli bireyler, yorucu fiziksel aktivitenin migren atakların tetikleyebileceğini bildirmektedir (20). Migrene sahip 7000'den fazla bireyi kapsayan sistematik bir derlemede, egzersiz ve/veya efor şeklindeki fiziksel aktivite migrenli bireylerin yaklaşık \%25'i tarafindan tetikleyici bir faktör olarak rapor edilmiştir (21). Sonuç olarak literatürde migren ve fiziksel aktivitenin ilişkisi konusunda tartışmalı sonuçlar mevcuttur. Migren ve fiziksel aktivite arasındaki ilişkinin değerlendirilmesine ihtiyaç olduğu belirtilmektedir (22). Bunlara ek olarak araştırmalarımız sonucunda migrenden muzdarip olan 
bireylerde migrenin kapsamlı klinik özellikleri ile fiziksel aktivite arasındaki ilişkinin incelendiği herhangi bir çalışmaya da rastlanmamıştır.

Bu doğrultuda çalışmanın amacı, migrenli bireylerin klinik özelliklerini belirlemek ve bu özellikler ile fiziksel aktivite arasındaki ilişkiyi saptamaktı.

\section{GEREÇ VE YÖNTEMLER}

\section{Araştırmanın Türü}

$\mathrm{Bu}$ çalışma, kesitsel bir çalışma olarak tasarlandı.

\section{Örneklem}

Çalışmaya Uluslararası Baş Ağrısı Topluluğu kriterlerine uygun olarak nörolog tarafından migren tanısı konan 18-65 yaş aralığında, çalışmaya katılmaya gönüllü son üç ayda en az üç migren atağına sahip olan bireyler dahil edildi. Diğer birincil ve/veya ikincil baş ağrıları, gebelik veya gebelik şüphesi, malignite öyküsü, mental ve/veya kooperasyon problemi, ciddi psikiyatrik bozukluk, migren dişında herhangi bir nörolojik (Parkinson hastalığı, multipl skleroz vb.) hastalığa sahip olan, okuryazar olmayan, değerlendirme ölçek ve anketlerinde eksik bilgi veren bireyler çalışmaya dahil edilmedi (Şekil-1). Duyurular yoluyla migrenli bireyler dahil edilme ve çıkartılma kriterlerine uygun olarak kartopu örnekleme yöntemi ile seçildi.

\section{Verilerin Toplanması}

Kasım 2020 ile Şubat 2021 tarihleri arasında çevrim içi (online) bir form aracılığıyla web tabanlı bir çalışma olarak gerçekleştirildi.

\section{Veri Toplama Araçları}

Tüm katılımcıların; fiziksel-demografik bilgileri ve migrene eşlik eden semptomları sorgulanıp kaydedildi. Ardından ağrı şiddeti; Numerik Ağrı Derecelendirme Skalası (NADS) ile migrene bağlı özürlülük düzeyi Migren Özür Değerlendirme Skalası (MÖDS) ile baş ağrısına bağlı bireyin etkilenimini Baş Ağrısı Etki Ölçeği (BAEÖ) ile fiziksel aktivite düzeyleri Uluslararası Fiziksel Aktivite Anketi ile değerlendirildi.

\section{Fiziksel-Demografik Bilgi ve Migrene Eşlik Eden Semptom Sorgulama Formu}

Araştırmacılar tarafından oluşturulan bu form migrenli bireylerin fiziksel-demografik bilgilerini sorgulamaya yönelik; yaş, cinsiyet, medeni durum, eğitim seviyesi, çalışma durumu, vücut kütle indeksi (VKİ), sigara ve alkol kullanımı sorularını içerdi. İlaveten migrene eşlik eden semptomlar ile ilgili olarak; atak süresi, atak sıklığı, atak sırasında aura varlığı, auranın tipi (görsel aura, işitsel aura, konuşma aurası, duyusal aura), boyun ağrısı, baş dönmesi, bulantı, kusma, fotofobi (ışığa karşı hassasiyet), fonofobi (sese karşı hassasiyet), osmofobi (kokuya karşı hassasiyet), ailede migren öyküsü varlığı, fibromiyalji varlığı ve temporamandibular disfonksiyon varlığı (çene ekleminde; açma-kapama ve/veya palpasyonda ağrı, eklem hareketi esnasında gelen ses, ağız açma hareketinde kısıtlılık) soruları yer almaktaydı. 


\section{Numerik Ăgrı Derecelendirme Skalası}

Bireylerin son bir aydaki ortalama ağrı şiddeti, Numerik Ağrı Derecelendirme Skalası (NADS) ile değerlendirildi. NADS, 0-10 arası puanlamadan oluşmaktadır. " $0=$ Hiç ağrı yok" anlamına gelirken, "10=Dayanılmaz ağrı" anlamına gelmektedir. Bireylerden son bir ayda hissettikleri ağrı şiddetini puanlamaları istendi.

\section{Migren Özür Değerlendirme Skalası}

Migrene bağlı özür durumu, Türkçe geçerlik ve güvenirliği Ertaş ve ark. (2004) tarafından çalışılmış olan Migren Özür Değerlendirme Skalası (MÖDS) ile değerlendirildi (23). MÖDS; baş ağrısı nedeniyle son üç ay içinde işe veya okula gidilemeyen gün sayısını, ev işlerinin yapılamadığı gün sayısını, sosyal ve boş zaman aktivitelerinin yapılamadığı gün sayısını ve iş veya okul aktiviteleri ile ev işlerinin tamamen yapılamadı $\breve{g}_{1}$ veya veriminin azaldığı gün sayısını sorgulayasını hesaplayan beş sorudan oluşmaktadır. Toplam puan üzerinden MÖDS skoru elde edilir. Puan aralıkları; puan 0-5: 1. Derece (hiç veya çok az kayıp), puan 6-10: 2. Derece (hafif kayı), puan 11-20: 3. Derece (orta derecede kayip), puan 21 ve üzeri: 4. Derece (ciddi kayıp) olarak hesaplanmaktadır (23).

\section{Baş Ağrısı Etki Ölçeği}

Migrenli bireylerde baş ağrısına bağlı yaşam kalitesini değerlendirmek amacıyla Baş Ağrısı Etki Ölçeği (BAEÖ) kullanıldı. Ölçeğin Türkçe geçerlik ve güvenirliği Dikmen ve ark. (2020) tarafından yapılmıştır (24). Baş ağrısının sıklığını, baş ağrısına bağlı olarak günlük olağan faaliyetleri yürütme becerisi, sosyal yaşamdaki kısıtlanma derecesi, dinlenme ihtiyacı ve duygu durumundaki değişikliğini içeren altı ayrı sorudan oluşmaktadır. Bu ölçek 36 ile 78 arasında puan alabilmektedir. Bu ölçekte alınan daha yüksek puanlar bireyin yaşam kalitesi etkileniminin arttığını gösterir. Birinci derece ölçek puanı $\leq 49$ ise etkilenme yok, ikinci derece 50-55 ise orta düzey etkilenme, üçüncü derece 56-59 ise belirgin etkilenme, dördüncü derece $\geq$ 60 ise şiddetli etkilenme olarak değerlendirilir (24).

\section{Uluslararası Fiziksel Aktivite Anketi}

Fiziksel aktivite düzeyi, Türkçe geçerlik ve güvenirliği Sağlam ve ark. (2010) tarafindan çalışılmış olan Uluslararası Fiziksel Aktivite Anketi'nin (UFAA) kısa formu kullanılarak değerlendirildi (25). Yedi sorudan oluşan anket; oturma, yürüme, orta düzeyde şiddetli aktiviteler, şiddetli aktivitelerde harcanan zaman hakkında bilgi vermektedir. Toplam puan yürüme, orta-şiddetli, şiddetli aktivite ve bu aktivitelerin süresi (dakika) ve frekansı (gün) toplanarak hesaplanmaktadır. Bütün aktivitelerin değerlendirilmesinde bu aktivitelerin tek seferde en az 10 dakika yapılıyor olması gerekmektedir. Bu hesaplamalardan metabolik eşdeğer (MET) değeri, gün, dakika çarpılarak bir skor elde edilir. Yürüme puanı hesaplanırken, yürüme süresi 3.3 MET ile; orta düzeyde şiddetli aktivite puanı hesaplanırken 4 MET ile; şiddetli aktivite puanı hesaplanırken 8 MET değeri ile çarpılır. Fiziksel aktivite düzeyleri; fiziksel olarak inaktif (<600 MET-dk/hafta), minimal aktif (600-3000 MET-dk/hafta), aktif (>3000 MET-dk/hafta) olarak sinıflandırılır (25). 


\section{İstatistiksel Analiz}

Değişkenlerin normal dağılıma uygunluğu görsel (histogram ve olasıllık grafikleri) ve analitik yöntemler (Kolmogorov-Smirnov testi) ile incelendi. Tanımlayıcı analizler normal dağılım gösteren değiş̧kenler için ortalama (X) ve standart sapma (SS), normal dağılım göstermeyen değişkenler için ortanca ve minimum-maksimum (min-maks) değerleri ve ordinal değişkenler için frekans (n) ve yüzde (\%) değerleri kullanılarak verildi. Migrenli bireylerin son bir ayda yaşadığı ağrı şiddeti, süresi ve sıklığı ile fiziksel aktivite düzeyi arasındaki ilişki Spearman korelasyon testi ile analiz edildi. İstatistiksel analizler ve hesaplamalar için IBM SPSS Statistics 21.0 (IBM Corp. Released 2012. IBM SPSS Statistics for Windows, Version 21.0. Armonk, New York, ABD) kullanıldı. İstatistiksel yanılma olasılığı $\mathrm{p}<0.05$ olarak kabul edildi.

\section{Araştırmanın Etik Yönü}

Çalışma, Ankara Yıldırım Beyazıt Üniversitesi Etik Kurulu tarafından onaylandı (Onay tarihi: 09.11.2020, onay karar no: 8) ve Helsinki Bildirgesi ilkelerine uygun biçimde yürütüldü. Katılımcılar, çalışma hakkında bilgilendirildi ve onamları alındı.

\section{BULGULAR}

Çalı̧̧maya 363 migrenli birey alındı. Elli üç birey dahil edilme kriterlerine uymaması nedeni ile çalışma dışı bırakıldı. Çalışmayı toplam 310 birey tamamladı (Şekil 1). Bireylerin \%86.5'i (n=268) kadın ve \%57.7'sinin ( $\mathrm{n}=179)$ bekar olduğu, \%58.7'sinin $(\mathrm{n}=182)$ de çalıştı̆ı görüldü. Çalışmaya katılan fiziksel ve demografik özelliklerine ait tanımlayıcı bulgular tablo şeklinde sunuldu (Tablo 1).

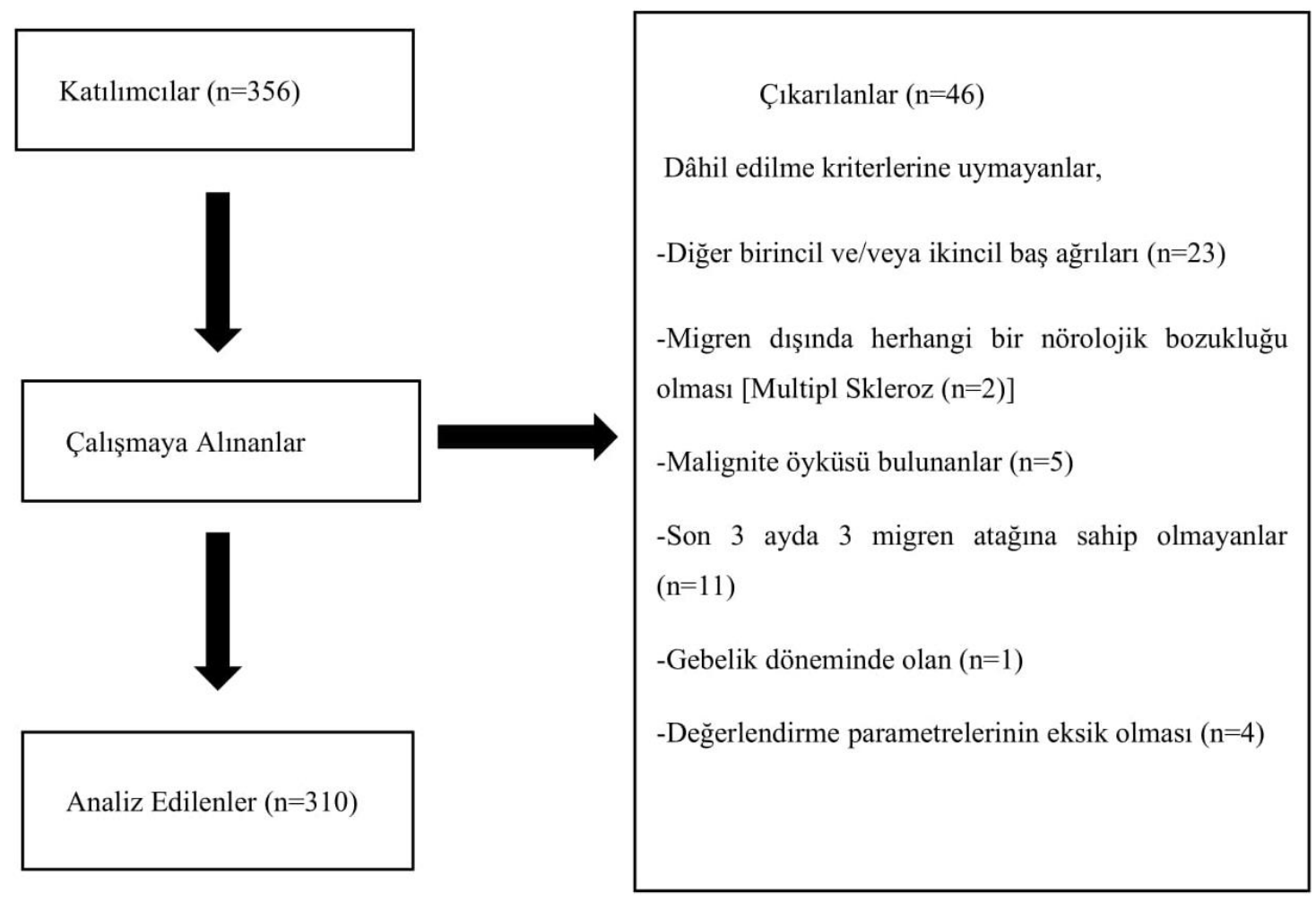

Şekil 1. Katılımcıların Akış Şeması 
Tablo 1. Bireylerin Fiziksel ve Demografik Özellikleri.

\begin{tabular}{|c|c|}
\hline Fiziksel ve Demografik Özellikler & Migrenli Bireyler $(\mathrm{n}=\mathbf{3 1 0})$ \\
\hline Yaş (yıl), $\mathrm{X} \pm \mathrm{SS}$ & $31.13 \pm 7.35$ \\
\hline Vücut Kütle İndeksi $\left(\mathrm{kg} / \mathrm{m}^{2}\right), \mathrm{X} \pm \mathrm{SS}$ & $24.03 \pm 4.67$ \\
\hline \multicolumn{2}{|l|}{ Cinsiyet, $\mathbf{n}(\%)$} \\
\hline Kadin & $268(86.50)$ \\
\hline Erkek & $42(13.50)$ \\
\hline \multicolumn{2}{|l|}{ Eğitim durumu, n (\%) } \\
\hline İlkokul & $9(2.9)$ \\
\hline Ortaokul & $5(1.6)$ \\
\hline Lise & $23(7.4)$ \\
\hline Lisans & $273(88.1)$ \\
\hline \multicolumn{2}{|l|}{ Çalışma durumu, n (\%) } \\
\hline Çalışıyor & $182(58.7)$ \\
\hline Çalışmiyor & $128(41.3)$ \\
\hline Sigara, n (\%) & $87(28.1)$ \\
\hline Alkol, n (\%) & $57(18.4)$ \\
\hline
\end{tabular}

Migrenli bireylerin son bir aydaki ortalama ağrı şiddeti, atak sayısı ve süresi sırasıyla 8 (4-10), 4 (1-30) ve 120 (50-4320) dk olarak bulundu. Bireylerin \%77.7 ( $\mathrm{n}=241)$ 'sinde ailede migren öyküsü mevcuttu. Migrenli bireylerin \%89.7 $\operatorname{sinin}(n=278)$ aura yaşadığı, aura tiplerinden de en çok $(\% 65.2 ; n=202)$ görsel aura yaşadıkları saptandı. Bireyler atak sırasında en çok fotofobi ( $\% 91.3 ; n=283)$ ve fonofobi $(\% 95.2 ; n=295)$ şikayeti olduğu saptandı. Migrenli bireylerde en çok boyun ağrısı (\%80.6; n=250) şikayeti olduğu bulundu. Bu çalışmada MÖDS skorlarına göre en çok ciddi fonksiyonel kayıp (\%57.7; n=179), BAEÖ skorlarına göre de yaşam kalitesinde en çok şiddetli etkilenim $(\% 88.7 ; n=275)$ olduğu tespit edildi. Migrenli bireylerin klinik parametreleri tablo halinde gösterildi (Tablo 2).

Tablo 2. Migrenli Bireylerin Klinik Parametreleri.

\begin{tabular}{|c|c|}
\hline Klinik Parametreler & $\begin{array}{c}\text { Ortanca (min-maks) } \\
n(\%) \\
\end{array}$ \\
\hline \multicolumn{2}{|l|}{ Ağrı karakteristiği } \\
\hline Ağr1 şiddeti & $8(4-10)$ \\
\hline Atak sayısı & $4(1-30)$ \\
\hline Atak süresi (dk) & $120(50-4320)$ \\
\hline Ailede migren hikayesi & $241(77.7)$ \\
\hline Aura varlığı & $278(89.7)$ \\
\hline \multicolumn{2}{|l|}{ Aura tipi } \\
\hline Görsel & $202(65.2)$ \\
\hline İşitsel & $155(50.0)$ \\
\hline Konuşma & $147(47.4)$ \\
\hline Duyusal & $170(54.8)$ \\
\hline \multicolumn{2}{|l|}{ Eşlik eden semptomlar } \\
\hline Mide bulantısı & $251(81.0)$ \\
\hline Kusma & $102(32.9)$ \\
\hline Fotofobi & $283(91.3)$ \\
\hline Fonofobi & $295(95.2)$ \\
\hline Osmofobi & $221(71.3)$ \\
\hline Kuteneal allodini & $202(65.2)$ \\
\hline
\end{tabular}


Tablo 2. Migrenli Bireylerin Klinik Parametreleri (devam).

\begin{tabular}{cc}
\hline Eşlik eden kas-iskelet problemleri & \\
Fibromiyalji & $33(10.6)$ \\
Boyun ağrısı & $\mathbf{2 5 0}(\mathbf{8 0 . 6})$ \\
Temporamandibular disfonksiyonu & $34(11)$ \\
\hline Migrene bağlı özür durumu (MÖDS) & $18(5.8)$ \\
Hiç & $34(11.0)$ \\
Hafif özür & $79(25.5)$ \\
Orta özür & $\mathbf{1 7 9 ( 5 7 . 7 )}$ \\
Ciddi özür & $5(1.6)$ \\
Etkilenim yok & $11(3.5)$ \\
Orta etkilenim & $19(6.2)$ \\
Belirgin etkilenim & $\mathbf{2 7 5 ( 8 8 . 7 )}$ \\
Şiddetli etkilenim &
\end{tabular}

Migrenli bireylerin UFAA skoru 1188.0 (49.50-7572.0) olarak bulundu. Bu ölçeğe göre bireylerin fiziksel aktivite düzeyleri sırasıyla \%29.0'u (n=90) inaktif, \%57.1'i (n=177) minimal aktif ve \%13.9'u (n=43) aktif idi.

Çalışmanın sonucunda; migrenli bireylerde fiziksel aktivite düzeyi ile ağrı şiddeti (rho=$0.022 ; \mathrm{p}=0.730$ ), atak sayıs1 ( $\mathrm{rho}=0.070 ; \mathrm{p}=0.221$ ) ve süresi ( $\mathrm{rho}=-0.057 ; \mathrm{p}=0.318)$, migrene bağlı özür durumu (rho=0.005; $\mathrm{p}=0.932)$ ve yaşam kalitesi $(\mathrm{rho}=-0.021 ; \mathrm{p}=0.714)$ arasında anlamlı bir ilişki olmadığı görüldü (Tablo 3).

Tablo 3. Migrenli Bireylerin Fiziksel Aktivite Düzeyi ile Ağrı Karakteristiği, Özür Durumu ve Yaşam Kalitesi Arasındaki İlişki.

\begin{tabular}{ccc}
\hline & \multicolumn{2}{c}{ UFAA skoru } \\
\cline { 2 - 3 } & \multicolumn{2}{c}{ rho } \\
\hline Ağrı karakteristiği & & p \\
\hline Ağrı şiddeti & -0.022 & 0.703 \\
Atak sayısı & 0.070 & 0.221 \\
Atak süresi & -0.057 & 0.318 \\
\hline Migrene bağlı özür durumu ve yaşam kalitesi & & \\
\hline MÖDS skoru & 0.005 & 0.932 \\
BAEÖ skoru & -0.021 & 0.714 \\
\hline
\end{tabular}

*p<0,05, rho: Spearman korelasyon katsayıs1, MÖDS: Migrene Bağlı Özür Durumu, BAEÖ: Baş Ağrısı Etki Ölçeği, UFAA: Uluslararası Fiziksel Aktivite Anketi

\section{TARTIŞMA}

Bu çalışmada, migrenli bireylerde atak sırasında şiddetli ağrı yaşandığı, auranın yüksek oranda eşlik ettiği en çok görsel auranın yaşandığı, atak sırasında en çok fotofobi ve fonofobi şikayetleri olduğu görüldü. Ayrıca migrenli bireylerin büyük çoğunluğunun boyun ağrısı yaşadığı saptandı. Bu örneklemde migrene bağlı özür durumunun ve yaşam kalitesinin çok fazla etkilendiği görüldü. Bireylerin büyük bir çoğunluğunun fiziksel olarak aktif olmadığı bulundu. Ayrıca fiziksel aktivite düzeyi ile migrenin klinik semptomları, migrene bağlı özür durumu ve yaşam kalitesi etkilenimi arasında anlamlı bir ilişki saptanmadı.

Migren baş ağrıları diğer baş ağrılarına göre daha şiddetli ve uzun sürelidir. Ayrıca daha çok özüre neden olur (26). Rasmussen ve ark. (1991) yaptıkları bir çalışmada, migrenli bireylerin ağrı şiddetinin genellikle orta şiddette ve şiddetli olduğunu ve \%85'inin şiddetli baş ağrısı yaşadığını ifade etmiştir. Atak süresinin de auralı ve aurasız grupta 4sa-24 sa aralığında 
daha yüksek seviyede olduğunu bulmuşlardır (2). Almanya'da yapılan diğer bir çalışmada ise migrenli bireylerin \%66'sının ayda bir veya iki gün atak öyküsü, ortalama atak sayısı ayda 2.82 gün, ağrı şiddeti bireylerin \%60'indan fazlasında şiddetli ve \%36'sında orta düzeyde olduğu ifade edilmiştir (27). Türk toplumuna bakıldığındaysa Ertaş ve ark. (2012) tarafından yapılan bir çalışmada; ortalama atak sayısının ayda yaklaşık altı gün olduğu ve migrenli bireylerin yarısından fazlasının baş ağrısı ataklarının şiddetli olduğu bildirilmiştir (28). Literatürdeki çalışmalarla benzer olarak, çalışmamızda migrenli bireylerin son bir ayda atak sırasında genellikle şiddetli ağrı yaşadıklarını tespit edildi. Aynı zamanda son bir ayda ortalama atak sayısını dört ve süresini $120 \mathrm{dk}$ olarak bulundu.

Migrende baş ağrısına eşlik eden başlıca semptomlar; mide bulantısı, kusma, fotofobi ve fonofobi vb. klinik özelliklerdir (1). Lipton ve ark. (2001) yılında yaptı̆̆ çalışmada fotofobi $\% 80$, fonofobi $\% 76$, mide bulantıs1 $\% 73$ ve kusma $\% 29$ olarak bulmuştur (29). Türk toplumunda Ertaş ve ark. (2012) yaptığ 1 çalışmada da benzer şekilde, fonofobi \%85.2, fotofobi $\% 82.5$, mide bulantısı veya kusma \%80.8 oranında tespit etmiştir (28). Çalışmamızda da benzer şekilde atak sırasında en çok yaşanan semptomların fonofobi (\%95.2) ve fotofobi (\%91.3) olduğu bulundu.

Migren, auralı ve aurasız olmak üzere iki ana alt başlıkta toplanmaktadır. Aurasız migren, belirli özellikleri ve ilişkili semptomları olan baş ağrısı ile karakterize klinik bir sendromdur. Auralı migren, genellikle baş ağrısından önce veya bazen eşlik eden geçici fokal nörolojik semptomlarla karakterizedir (3). Hem kadınlarda hem de erkeklerde aurasız migren, auralı migrene göre daha yaygın olarak ifade edilmektedir (30). Tayvan'da yapılan bir çalışmada auralı migren oranı \%12.5 gözlenmişken (31), İsveç’te yapılan diğer bir çalışmada migrenli bireylerin \%26'sının aurayı deneyimlediği sonucuna varılmıştır (32). Ayrıca Kore'de yapılan başka bir çalışmada auralı migren oranı toplamda $\% 46.6$ olarak diğer çalışmalara göre daha yüksek değerler elde edilmiştir (33). Türk toplumunda da yapılan prevalans çalışmasında migrenli bireylerde aura oranını \%21.5 olarak ifade ederken (28), Börü ve ark.'nın (2005) migrenli kadınlarda yaptıkları çalışmada auralı migren oranını çok daha yüksek (\%53.1) bulmuştur (34). Çalışmamızda ise bireylerin \%89.7'si son 1 ay içinde yaşadıkları ataklar sırasında görsel, işitsel, konuşma ve duyusal auradan en az birini yaşadıkları belirlendi ve bireylerin yüksek oranda aura yaşadığı saptandı. Auralı migrenin farklı toplumlar arasında ve aynı toplum içerisinde farklı oranda görülmesi sebebinin değerlendirilen migrenli gruplardaki yaş, cinsiyet, migrene bağlı etkilenim ve bireysel farklılıklar gibi etkenlerin değişkenliklerinden kaynaklandığı düşünülmektedir. Ayrıca migrenli bireylerde meydana gelen en yaygın aura fenomeni görsel auradır. Daha sonra sırasıyla duyusal, konuşma ve motor aura gelmektedir $(5,35)$. Çalışmamızda literatür ile benzer şekilde en yüksek değerleri \% 65.2 oranıyla görsel aura alırken bunu \%54.8'le duyusal aura, \%50.0'le işitsel aura ve \%47.4'le konuşma aurası takip etmektedir. Migrenli bireylerin yaklaşık \%74'ünün boyun ağrısından muzdarip olduğu görülen çalışmaları $(36,37)$ doğrular nitelikte çalışmamızda da migrenli bireylerde eşlik eden kas iskelet problemleri arasından ilk sırada boyun ağrısı (\%80.6) şikayeti olduğunu görüldü. Migren, bireyin günlük yaşamında özre ve yaşam kalitesinin bozulmasına da neden olan kronik bir problemdir (26). Çalışmamızda MÖDS skorlarına göre en çok ciddi fonksiyonel kayıp (\%57.7), BAEÖ skorlarına göre migrene bağlı yaşam kalitesinde en çok şiddetli etkilenim (\%88.7) olduğu tespit edildi. 
Fiziksel aktivite ya da egzersiz ile migren arasındaki ilişki oldukça tartışmalıdır (38). Fiziksel aktivite sırasında veya sonrasında migren ağrısının kötüleştiğini ve migren atağının tetiklendiğini bildiren çalışmalar vardır (39). Amerika Birleşik Devletleri'nde 13 ile 80 yaşları arasındaki 1207 hasta üzerinde yapılan bir prospektif klinik temelli bir çalışmada, bireylerin \%22'si arasında fiziksel aktivitenin migren için tetikleyici bir faktör olduğu bildirilmiştir (40). Migrene sahip 103 birey üzerinde yapılan prospektif diğer bir çalışmada ise migren hastaları arasında egzersizle tetiklenen migren ataklarının yaşam boyu yaygınlığını \%38 olarak bildirmişlerdir. Ayrıca egzersize bağlı tetiklenen migren atakları bildiren hastaların yarısından fazlası migren nedeniyle egzersiz yapmayı terk ettiği saptanmıştır (41). Egzersizin migren ataklarını nasıl tetikleyebileceğine ilişkin olası mekanizmaları açıklarken kalsitonin geni ile ilişkili peptid gibi nöropeptidlerin akut salımını veya hipokretin veya laktat metabolizmasının değişimini içerdiğini iddia edilmektedir (38). Diğer yandan fiziksel aktivite veya egzersizin migren ataklarının sıklığını, yoğunluğunu ve/veya süresini azaltmaya yardımcı olabileceğini ifade eden çalışmalar da mevcuttur (14-16). Egzersizin migreni önleme mekanizmasının temelinde de egzersiz sonrası plazmada artmış beta-endorfin, endokannabinoid ve beyinden türetilen nörotrofik faktör yer almaktadır (38). Lebedeva ve ark. (2016) migren gelişme riski ile ilişkili olabilecek potansiyel yaşam tarzı faktörlerini belirlemek amacıyla görüştükleri 3.124 migrenli bireyi dahil ettikleri çalışma sonucunda düşük fiziksel aktivitenin (haftada <30 dakika), \%60 daha yüksek migren gelişme riski ile ilişkili olduğunu bulmuşlardır (42). Düşük fiziksel aktivite seviyeleri ile migren ve diğer baş ağrılarının daha yüksek yaygınlığı ve sıklığı ile ilişkili olduğu ifade edilmektedir $(17,18)$. Çalışmamızda da literatüre benzer olarak şiddetli migren atakları yaşayan bireylerin sadece \%13.9'u fiziksel olarak aktif bulundu. Literatürde migrenli bireyler diğer baş ağrısına ve sadece boyun ağrısına sahip gruplara göre fiziksel aktivite yapma becerilerinin azaldığ 1 da bildirilmiştir (43). Bu konu ile ilgili olarak çalışmamızdaki bireylerin yarısından fazlasının migrene bağlı özür durumu ve yaşam kalitesinin ciddi etkilenime sahip olduğu ayrıca dikkate çekicidir. Bireylerdeki migrene bağlı bu ciddi etkilenim fiziksel aktivite seviyesinin düşük olmasında rol oynamış olabilir. Ayrıca çalışmamız tüm dünyada 2019 yılında başlayan ve hala devam etmekte olan COVID-19 pandemi döneminde gerçekleştirilmiştir. Pandemi sürecinde uygulanan karantina ve sosyal izolasyon gibi uygulamaların da bireylerdeki fiziksel aktivite seviyesini olumsuz yönde etkilemiş olabilir.

Bunlara ek olarak çalışmamızda migrenli bireylerde fiziksel aktivite düzeyi ile ağrı şiddeti, atak sayısı ve süresi, migrene bağlı özür durumu ve yaşam kalitesi etkilenimi arasında anlamlı bir ilişki olmadığı saptandı. Bu durum düşük fiziksel aktivitenin migrenin bir sonucu mu yoksa sebebi mi olduğu hala belirsiz olmasından kaynaklanabilir (38). Buna ek olarak fiziksel aktivite ve ağrı karakteristiği, migrene bağlı özür durumu ve yaşam kalitesi arasındaki ilişkinin görülmeme nedeni subjektif değerlendirme yöntemlerine de bağlı olabilir. İleriki çalışmalarda bu konunun daha detaylı olarak araştırılması gerekmektedir.

Çalışmamızın limitasyonu migrenli bireylerin fiziksel aktivite düzeyini Türkçe uyarlamasının geçerli ve güvenilir olduğu bir anket ile subjektif olarak değerlendirildi. Fiziksel aktivite düzeyinin migrenli bireylerin ağnı özellikleri, özür ve yaşam kalitesi ile ilişkisinin inceleneceği, daha objektif yöntemler (pedometre, akselerometre vb.) ile fiziksel aktivite düzeyinin değerlendirildiği çalışmalara ihtiyaç vardır. 


\section{SONUÇ VE ÖNERİLER}

Çalışmamızda migrenli bireylerin klinik özelliklerini belirlemek ve bu özellikler ile fiziksel aktivite arasındaki ilişkiyi saptamak amacıyla gerçekleştirildi. Çalışma sonucunda, migrenli bireylerde atak sırasında şiddetli ağrı yaşandığı, auranın yüksek oranda eşlik ettiği ve en çok görsel auranın yaşandığı görüldü. İlaveten atak sırasında en çok fotofobi ve fonofobi şikayetleri olduğu tespit edildi. Migrenle ilişkili en çok ciddi özür durumu olduğu ve yaşam kalitesinde en çok şiddetli etkilenimin olduğu tespit edildi. Değerlendirdiğimiz migrenli bireylerin sadece \%13.9'unun fiziksel olarak aktif olduğu belirlendi. Fakat fiziksel aktivite düzeyi ile ağrı karakteristiği, özür durumu ve yaşam kalitesi arasında bir ilişki görülmedi.

\section{Araştırmanın Etik Yönü}

Çalışma, Ankara Yıldırım Beyazıt Üniversitesi Etik Kurulu tarafından onaylandı (Onay tarihi: 09.11.2020, onay karar no: 8) ve Helsinki Bildirgesi ilkelerine uygun biçimde yürütüldü. Katılımcılar, çalışma hakkında bilgilendirildi ve onamları alındı.

\section{Çıkar Çatışması}

Yazarlar arasında çıkar çatışması yoktur.

\section{KAYNAKLAR}

1. IHS, H. C. C. of the I. H. S. (2013). The international classification of headache disorders, (beta version). Cephalalgia, 33(9), 629-808.

2. Rasmussen, B. K., Jensen, R., Schroll, M. and Olesen, J. (1991). Epidemiology of headache in a general population - a prevalence study. JCE, 44(11), 1147-1157.

3. Olesen, J. (2018). Headache Classification Committee of the International Headache Society (IHS) the international classification of headache disorders, asbtracts. Cephalalgia, 38(1), 1-211.

4. Hansen, J. M., Goadsby, P. J. and Charles, A. C. (2016). Variability of clinical features in attacks of migraine with aura. Cephalalgia, 36(3), 216-224.

5. Viana, M., Sances, G., Linde, M., Ghiotto, N., Guaschino, E., Allena, M., et al. (2017). Clinical features of migraine aura: results from a prospective diary-aided study. Cephalalgia, 37(10), 979-989.

6. Demirkirkan, M. K., Ellidokuz, H., \& Boluk, A. (2006). Prevalence and clinical characteristics of migraine in university students in Turkey. Tohoku J Exp Med, 208(1), 87-92.

7. Şirin, T. C. (2017). Ağrı Devlet Hastanesine başvuran migren hastalarının klinik ve sosyodemografik özellikleri. Ege Tip Dergisi, 56(3), 128-134.

8. Kececi, H., \& Dener, S. (2002). Epidemiological and clinical characteristics of migraine in Sivas, Turkey. Headache, 42(4), 275-280.

9. Caspersen, C. J., Powell, K. E., \& Christenson, G. M. (1985). Physical activity, exercise, and physical fitness: definitions and distinctions for health-related research. Public Health Rep, 100(2), 126.

10. Ferguson, B. (2014). ACSM's Guidelines for Exercise Testing and Prescription 9th Ed. 2014. J Can Chiropr Assoc, 58(3), 328.

11. Landmark, T., Romundstad, P., Borchgrevink, P. C., Kaasa, S., \& Dale, O. (2011). Associations between recreational exercise and chronic pain in the general population: 
evidence from the HUNT 3 study. PAIN®, 152(10), 2241-2247.

12. Ellingson, L. D., Colbert, L. H., \& Cook, D. B. (2012). Physical activity is related to pain sensitivity in healthy women. Med Sci Sports Exerc, 44(7), 1401-1406.

13. Andrzejewski, W., Kassolik, K., Brzozowski, M., \& Cymer, K. (2010). The influence of age and physical activity on the pressure sensitivity of soft tissues of the musculoskeletal system. J Bodyw Mov Ther, 14(4), 382-390.

14. Busch, V., \& Gaul, C. (2008). Exercise in migraine therapy-is there any evidence for efficacy? A critical review. Headache, 48(6), 890-899.

15. Darling, M. (1991). The use of exercise as a method of aborting migraine. Headache, 31(9), 616-618.

16. Van Gijn, J. (1987). Relief of common migraine by exercise. J Neurol Neurosurg Psychiatry, 50(12), 1700.

17. Varkey, E., Hagen, K., Zwart, J. A., \& Linde, M. (2008). Physical activity and headache: results from the Nord-Trøndelag Health Study (HUNT). Cephalalgia, 28(12), 12921297.

18. Wöber, C., Brannath, W., Schmidt, K., Kapitan, M., Rudel, E., Wessely, P., et al. (2007). Prospective analysis of factors related to migraine attacks: the PAMINA study. Cephalalgia, 27(4), 304-314.

19. Martins, I. P., Gouveia, R. G., \& Parreira, E. (2006). Kinesiophobia in migraine. J Pain, 7(6), 445-451.

20. Varkey, E., Sveälv, B. G., Edin, F., Ravn-Fischer, A., \& Cider, Å. (2017). Provocation of migraine after maximal exercise: a test-retest study. Eur Neurol, 78(1-2), 22-27.

21. Peroutka, S. J. (2014). What turns on a migraine? A systematic review of migraine precipitating factors. Curr Pain Headache Rep, 18(10), 454.

22. Pilati, L., Battaglia, G., Di Stefano, V., Di Marco, S., Torrente, A., Raieli, V., et al. (2020). Migraine and Sport in a Physically Active Population of Students: Results of a Cross-Sectional Study. Headache, 60(10), 2330-2339.

23. Ertaş, M., Siva, A., Dalkara, T., Uzuner, N., Dora, B., Inan, L., et al. (2004). Validity and reliability of the Turkish Migraine Disability Assessment (MIDAS) questionnaire. Headache, 44(8), 786-793.

24. Yalınay Dikmen, P., Bozdag, M., Gunes, M., Kosak, S., Tasdelen, B., Uluduz, D. ve Ozge, A. (2020). Reliability and validity of Turkish version of Headache Impact Test (HIT-6) in patients with migraine. Arch Neuropsychiatry, 1-8.

25. Saglam, M., Arikan, H., Savci, S., Inal Ince, D., Bosnak Guclu, M., Karabulut, E., et al. (2010). International physical activity questionnaire: reliability and validity of the Turkish version. Percept Mot Skills, 111(1), 278-284.

26. Stewart, W. F., Shechter, A., \& Lipton, R. B. (1994). Migraine heterogeneity. Disability, pain intensity, and attack frequency and duration. Neurology, 44(6 Suppl 4), S24-39.

27. Göbel, H., Petersen-Braun, M., \& Soyka, D. (1994). The epidemiology of headache in Germany: a nationwide survey of a representative sample on the basis of the headache classification of the International Headache Society. Cephalalgia, 14(2), 97-106.

28. Ertas, M., Baykan, B., Orhan, E. K., Zarifoglu, M., Karli, N., Saip, S., et al. (2012). Oneyear prevalence and the impact of migraine and tension-type headache in Turkey: a nationwide home-based study in adults. J Headache Pain, 13(2), 147-157.

29. Lipton, R. B., Stewart, W. F., Diamond, S., Diamond, M. L., \& Reed, M. (2001). Prevalence and burden of migraine in the United States: data from the American Migraine Study II. Headache, 41(7), 646-657.

30. Russell, M. B., Rasmussen, B. K., Thorvaldsen, P. E. R. and Olesen, J. E. S. (1995). Prevalence and sex-ratio of the subtypes of migraine. Int J Epidemiol, 24(3), 612-618.

31. Wang, S. J., Fuh, J. L., Young, Y., Lu, S. R., \& Shia, B. C. (2000). Prevalence of 
migraine in Taipei, Taiwan: a population-based survey. Cephalalgia, 20(6), 566-572.

32. Dahlöf, C., \& Linde, M. (2001). One-year prevalence of migraine in Sweden: a population-based study in adults. Cephalalgia, 21(6), 664-671.

33. Roh, J. K., Kim, J. S., \& Ahn, Y. O. (1998). Epidemiologic and clinical characteristics of migraine and tension-type headache in Korea. Headache, 38(5), 356-365.

34. Börü, Ü. T., Koçer, A., Lüleci, A., Sur, H., Tutkan, H., \& Atli, H. (2005). Prevalence and characteristics of migraine in women of reproductive age in Istanbul, Turkey: a population based survey. Tohoku J Exp Med, 206(1), 51-59.

35. Russell, M. B., \& Olesen, J. (1996). A nosographic analysis of the migraine aura in a general population. Brain, 119(2), 355-361.

36. Ashina, S., Bendtsen, L., Lyngberg, A. C., Lipton, R. B., Hajiyeva, N., \& Jensen, R. (2015). Prevalence of neck pain in migraine and tension-type headache: a population study. Cephalalgia, 35(3), 211-219.

37. Florencio, L. L., Chaves, T. C., Carvalho, G. F., Gonçalves, M. C., Casimiro, E. C., Dach, F., et al. (2014). Neck pain disability is related to the frequency of migraine attacks: A cross-sectional study. Headache, 54(7), 1203-1210.

38. Amin, F. M., Aristeidou, S., Baraldi, C., Czapinska-Ciepiela, E. K., Ariadni, D. D., Di Lenola, D., et al. (2018). The association between migraine and physical exercise. $J$ Headache Pain, 19(1), 1-9.

39. Lippi, G., Mattiuzzi, C., \& Sanchis-Gomar, F. (2018). Physical exercise and migraine: for or against?. ATM, $6(10)$.

40. Kelman, L. (2007). The triggers or precipitants of the acute migraine attack. Cephalalgia, 27(5), 394-402.

41. Koppen, H., \& van Veldhoven, P. L. (2013). Migraineurs with exercise-triggered attacks have a distinct migraine. J Headache Pain, 14(1), 1-4.

42. Lebedeva, E. R., Kobzeva, N. R., Gilev, D. V., \& Olesen, J. (2016). Factors associated with primary headache according to diagnosis, sex, and social group. Headache, 56(2), 341-356.

43. Krøll, L. S., Hammarlund, C. S., Westergaard, M. L., Nielsen, T., Sloth, L. B., Jensen, R. H., et al. (2017). Level of physical activity, well-being, stress and self-rated health in persons with migraine and co-existing tension-type headache and neck pain. $J$ Headache Pain, 18(1), 1-9. 